\title{
Age and Chemistry of Dissolved Organic Carbon Reveal Enhanced Leaching of Ancient Labile Carbon at the Permafrost Thaw Zone
} Karis J. McFarlane ${ }^{1}$, Heather M. Throckmorton ${ }^{2,3}$, Jeffrey M. Heikoop ${ }^{2}$, Brent D. Newman ${ }^{2}$, Alexandra L. Hedgpeth ${ }^{1,4}$, Marisa N. Repasch ${ }^{1}$, Thomas P. Guilderson ${ }^{1,5}$, Cathy J. Wilson ${ }^{2}$

$5 \quad{ }^{1}$ Center for Accelerator Mass Spectrometry, Lawrence Livermore National Laboratory, Livermore, 94550, USA

${ }^{2}$ Earth and Environmental Sciences Division, Los Alamos National Laboratory, Los Alamos, 87545, USA

${ }^{3}$ Currently at Agilent Technologies, Lexington, 02421, USA

${ }^{4}$ Department of Geography, University of California, Los Angeles, 90095, USA

${ }^{5}$ Currently at University of California, Santa Cruz, 95064, USA

10 Correspondence to: Karis J. McFarlane (kjmcfarlane@llnl.gov)

\begin{abstract}
Climate change will alter the balance between frozen and thawed conditions in Arctic systems. Increased temperatures will make the extensive northern permafrost carbon stock vulnerable to decomposition and translocation. Production, cycling, and transport of dissolved organic carbon (DOC) are crucial processes for high-latitude ecosystem carbon loss that result in considerable export off the Arctic landscape. To identify where and under what conditions permafrost DOC

15 is mobilized in an Arctic headwater catchment, we measured radiocarbon $\left({ }^{14} \mathrm{C}\right)$ of DOC and assessed DOC composition with ultraviolet-visible spectroscopy (UV-vis), of surface waters and shallow and deep subsurface pore waters from 17 drainages in the Barrow Environmental Observatory in Alaska. Samples were collected in July and September 2013 to assess changes in age and chemistry of DOC over time. DOC age was highly variable ranging from modern $\left(19 \%\right.$ o $\left.{ }^{14} \mathrm{C}\right)$ to approximately 7000 y BP $\left(-583 \% \Delta^{14} \mathrm{C}\right)$. DOC age increased with depth, over the summer as the active layer deepened, and with increasing drainage size. DOC quality indicators reflected a DOC source rich in high-molecular weight and aromatic compounds throughout the summer and a weak relationship with DOC age. In deep porewaters, DOC age was also correlated with several biogeochemical indicators, suggesting a coupling between carbon and redox biogeochemistry influencing methane production. In the drained thawed lake basins included in this study, DOC concentrations and contributions of vegetation-derived organic matter declined with increasing basin age. The weak relationship between DOC age and chemistry and consistency in DOC chemical indicators over the summer suggest high lability of old DOC released by thawing permafrost.
\end{abstract}

\section{Introduction}

Soils of the northern permafrost region store nearly 1700 Pg of organic carbon (Tarnocai et al., 2009; Schuur et al., 2008). This extensive carbon pool is vulnerable to climate change as warmer temperatures increase thawing, microbial decomposition, fire frequency, and erosion (Schuur et al., 2013; Schuur et al., 2008). Loss of this permafrost carbon to the 
https://doi.org/10.5194/bg-2021-272

Preprint. Discussion started: 20 October 2021

(c) Author(s) 2021. CC BY 4.0 License.

(c) (i)

estimated $5-15 \%$ of permafrost soil carbon projected to be released to the atmosphere by the end of this century under the current warming trajectory (Schuur et al., 2015).

Carbon mobilized from thawing permafrost and warmer active-layer soils may be microbially transformed into carbon dioxide $\left(\mathrm{CO}_{2}\right)$ or methane $\left(\mathrm{CH}_{4}\right)$, which can be emitted directly to the atmosphere (Schadel et al., 2016; Hicks Pries et al.,

35 2013). Less well-studied than these direct fluxes to the atmosphere (Vonk et al., 2019), dissolved organic carbon (DOC) provides the carbon source for microbes and the subsequent production of gaseous fluxes (Charman et al., 1999; Chanton et al., 2008; Molot and Dillon, 1997; Corbett et al., 2013; Shirokova et al., 2013). Crucially, DOC also has the potential to be transported, potentially off the landscape through drainages, streams, and ultimately export to the ocean (Raymond et al., 2007; Holmes et al., 2011; Cole et al., 2007). Lateral transport of dissolved carbon is a crucial mechanism for terrestrial carbon loss

40 in the Arctic and results in an export off the landscape of up to $25 \%$ of net ecosystem productivity (calculated from Mcguire et al., 2009), exceeds net ecosystem exchange of carbon in some northern ecosystems (Aurela et al., 2002; Billett et al., 2004; Christensen et al., 2007; Roulet et al., 2007), and at the global scale is comparable in magnitude to the land and ocean $\mathrm{CO}_{2}$ sinks (Drake et al., 2018a; Tank et al., 2018).

DOC accounts for much of this carbon loss (Billett et al., 2004; Mcguire et al., 2009; Mcclelland et al., 2016), and

45 several studies have reported ancient radiocarbon ages for DOC in rivers, including 2000-500 yBP in erosion-impacted streams in the Kolyma River Basin (Mann et al., 2015) to over 20,000 yBP in streams freshly formed from thawing ice-rich Yedoma permafrost (Vonk et al., 2013). Furthermore, research shows that a substantial portion of this DOC (20-50\%) is labile (Mann et al., 2012; Mann et al., 2015; Holmes et al., 2008; Liu et al., 2019) and may be decomposed and released back to the atmosphere as $\mathrm{CO}_{2}$ or $\mathrm{CH}_{4}$ from soils, surface waters, or drainages (Kling et al., 1991; Cole et al., 2007; Drake et al., 2015).

50 In fact, increasing terrestrial DOC loads have been linked to increased $\mathrm{CO}_{2}$ emissions from aquatic systems (Lapierre et al., 2013).

The combination of melting permafrost, vegetation changes, increased snowfall and subsequent snowmelt is likely to result in an increase in the role of DOC as a mode of carbon transport within and across the Arctic landscape (Frey, 2005; Finlay et al., 2006; Kawahigashi et al., 2004). How the production and fate of terrigenous DOC will respond to future climate 55 change is not well constrained. Studies suggest that increasing temperature increases DOC production along with soil carbon 
https://doi.org/10.5194/bg-2021-272

Preprint. Discussion started: 20 October 2021

(c) Author(s) 2021. CC BY 4.0 License.

(c) (i)

decomposition (Neff and Hooper, 2002; Freeman et al., 2001). Increased DOC production is also expected as permafrost melts, active layers deepen, and shrub encroachment occurs (Frey and Mcclelland, 2009). However, numerous studies have shown that the fate of DOC is highly dependent on hydrology (Pastor et al., 2003; Kellerman et al., 2019; Raymond et al., 2016). Specifically, in wet years or in cases where hydrologic flow paths facilitate lateral movement of DOC to surface waters,

60 warming may increase DOC production, loss from terrestrial ecosystems, and export to surface waters (Freeman et al., 2001). This seems to be the current case for the Arctic as DOC export by streams and rivers increases with increasing streamflow, implying that DOC transport and production is water, not carbon, limited (Finlay et al., 2006; Raymond et al., 2007; Guo and Macdonald, 2006; Guo et al., 2007; Townsend-Small et al., 2011; Prokushkin et al., 2011). However, in drier conditions or when flow to surface waters is slow, DOC produced in soil and peat may be decomposed in situ, increasing soil and ecosystem

$65 \mathrm{CO}_{2}$ and $\mathrm{CH}_{4}$ fluxes to the atmosphere (Pastor et al., 2003). Alternatively, DOC may move down the soil profile where it may interact with mineral soils and be sorbed, stabilized, or remineralized to $\mathrm{CO}_{2}$ or $\mathrm{CH}_{4}$ (Fan et al., 2010; Frey and Mcclelland, 2009) and could provide a priming effect for decomposition of old carbon stores (Fan et al., 2010; Hayes et al., 2014; Wild et al., 2014).

Radiocarbon analyses and characterization of DOC provide insights into the sources, transfer, and lability of DOC 70 from arctic and subarctic ecosystems (Olefeldt and Roulet, 2012; Benner et al., 2004; Raymond et al., 2007; Guo and Macdonald, 2006; Amon and Meon, 2004) and can therefore provide crucial information about mechanisms behind carbon loss and transport that is not currently captured appropriately in high-latitude models. Large stores of inert yet labile permafrost carbon have, as a function of age, a unique ${ }^{14} \mathrm{C}$-isotopic signature that follows the carbon into the DOC pool. For example, very high concentrations of old DOC ( $\geq 20 \mathrm{ky}$ ) have been observed in streams with drainage basins encompassing thawing

75 Yedoma permafrost, demonstrating that actively thawing systems are, in fact, releasing large amounts of old, previously frozen carbon (Vonk et al., 2013). Furthermore, seasonal patterns of DOC loadings and ${ }^{14} \mathrm{C}$-age of DOC in arctic rivers exhibit a nearly consistent pattern with high concentrations of young (i.e., recently fixed) DOC following spring thaw, and slightly lower concentrations of DOC with an older ${ }^{14} \mathrm{C}$-age associated with baseflow (Guo and Macdonald, 2006; Guo et al., 2007; Raymond et al., 2007; Striegl et al., 2007; Neff et al., 2006; Amon et al., 2012; Wild et al., 2019). 
https://doi.org/10.5194/bg-2021-272

Preprint. Discussion started: 20 October 2021

(c) Author(s) 2021. CC BY 4.0 License.

(c) (i)

The molecular chemistry and biolability of DOC exported by large Arctic streams and rivers also change seasonally.

High flows associated with spring thaw contain higher amounts of relatively labile, vegetation and litter-derived DOC, but as streamflow decreases, DOC becomes both older and more depleted in compounds associated with vegetation inputs (Finlay et al., 2006; Neff et al., 2006; Holmes et al., 2008; Prokushkin et al., 2011; Striegl et al., 2007). For example, in large Arctic rivers, assessments of DOC optical properties have indicated higher aromaticity, lignin phenol concentrations, and molecular

85 weights associated with high flows during snowmelt (Spencer et al., 2008; Mann et al., 2016) and declines in aromaticity between summer and winter (O'donnell et al., 2012). A similar decline in aromaticity, assessed with ultraviolet-visible spectroscopy (UV-vis), of DOC in the Kolyma River and its tributaries from spring to late summer coincided with a decline in DOC ${ }^{14} \mathrm{C}$ values (Neff et al., 2006). Furthermore, a pan-Arctic study of DOC biodegradability assessed with incubations observed declines in biodegradability of DOC in large streams and rivers over the year (from January to December), likely

90 attributable to shifts in DOC source and hydrologic residence times as small streams and soil leachates showed no seasonal trends in the biolability of DOC (Vonk et al., 2015a).

The extent of permafrost thaw in Arctic watersheds also impacts DOC content and biolability in streams and rivers. In the pan-Arctic study listed above, continuous permafrost yielded higher amounts and lability of DOC in soil leachates than areas with discontinuous permafrost as assessed in laboratory incubations (Vonk et al., 2015a). Similarly, in the North Slope

95 of Alaska, rivers in watersheds with continuous permafrost had lower DOC concentrations with higher amounts of aliphatic compounds (indicative of microbial processing), while watersheds with more extensive permafrost thaw yielded DOC with characteristics indicative of unprocessed vegetation-derived organic matter including higher relative amounts of aromatics, polyphenols, and lignin (Johnston et al., 2021) .

The information gained from stream water samples is valuable, but these streams integrate processes across the

100 landscape and do not provide information about the locations within their watersheds where older or more labile $\mathrm{C}$ is being mobilized, limiting our ability to attribute these observations to processes. Yet, small watersheds and headwater streams remain understudied relative to large river basins (Vonk et al., 2015b; Shogren et al., 2019) even though these headwater catchments release DOC that is older and more biodegradable than larger rivers further along fluvial networks (Vonk et al., 2015a; Coch et al., 2019; Drake et al., 2018b; Textor et al., 2019). To bring us closer to identifying the conditions and processes influencing 
https://doi.org/10.5194/bg-2021-272

Preprint. Discussion started: 20 October 2021

(c) Author(s) 2021. CC BY 4.0 License.

(c) (i)

105 the production and transport of permafrost-derived DOC in headwater Arctic catchments, we measured DOC age $\left({ }^{14} \mathrm{C}\right)$ and chemistry of surface waters and soil porewaters in a survey of 17 drainages with different characteristics in the Barrow Environmental Observatory, Alaska. We integrate these new data $\left({ }^{14} \mathrm{C}\right.$ of DOC and UV-vis) with previously published biogeochemical tracers from the same sampling campaign (Throckmorton et al., 2015b) to elucidate the mechanisms behind DOC cycling across these drainages. This approach addresses some of the current challenges in this area of research by providing field implementation of biogeochemical tracers that can be used to infer changes in DOC cycling (Vonk et al., 2019). We hypothesized that in most drainages, DOC would become older and more enriched in aromatics and high molecular weight compounds over the course of the summer as active layers deepened, exposing organic matter that had not been microbially processed. We also expected to find spatial patterns in DOC age and chemistry reflecting differences in drainage characteristics such as a shift toward DOC sourced from older, more processed soil organic matter in older drained thaw lake basins as well

115 as with increasing catchment size.

\section{Materials and Methods}

\subsection{Study Area and Field Sampling}

The study area and sample collection have been described previously (Throckmorton et al., 2015b). Briefly, surface and pore water samples were collected in July and September of 2013 from 17 drainages in and around the Barrow Environmental Observatory on the Arctic Coastal Plain near Utqiavik, Alaska (71.3 $\mathrm{N}, 156.6^{\circ} \mathrm{W}$, Fig. 1). Sampling locations were along the periphery of internal and external drainages that included drained thaw lake basins of differing age, interlake basin areas, and different types of polygonal terrain. Sampling locations further classified by water flow, either "stagnant" wetlands (no observable flow during sampling) or "gentle flow" (channels with gentle lateral surficial flow was observed during sampling), although samples were collected from areas that appeared stagnant prior to sampling. Samples were collected

125 from three depths at each location: surface water, shallow subsurface soil porewater, and deep subsurface soil porewater. Grab samples were collected from surface waters at the edges of drainages. Shallow porewaters were collected with stainless steel drive points from $7.5-15 \mathrm{~cm}$ below the surface, which was typically organic soil. Deep porewaters were collected with macrorhizon samplers from the maximum depth to the frost table, which ranged from $27-64 \mathrm{~cm}$ below the surface and varied across 
https://doi.org/10.5194/bg-2021-272

Preprint. Discussion started: 20 October 2021

(c) Author(s) 2021. CC BY 4.0 License.

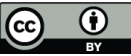

sites and sampling month (34 $\mathrm{cm}$ in July and $43 \mathrm{~cm}$ in September, on average). Samples were filtered in the field through 0.45

or $0.2 \mu \mathrm{m}$ Fisherbrand nylon syringe filters, depending on the analyte of interest (see below).

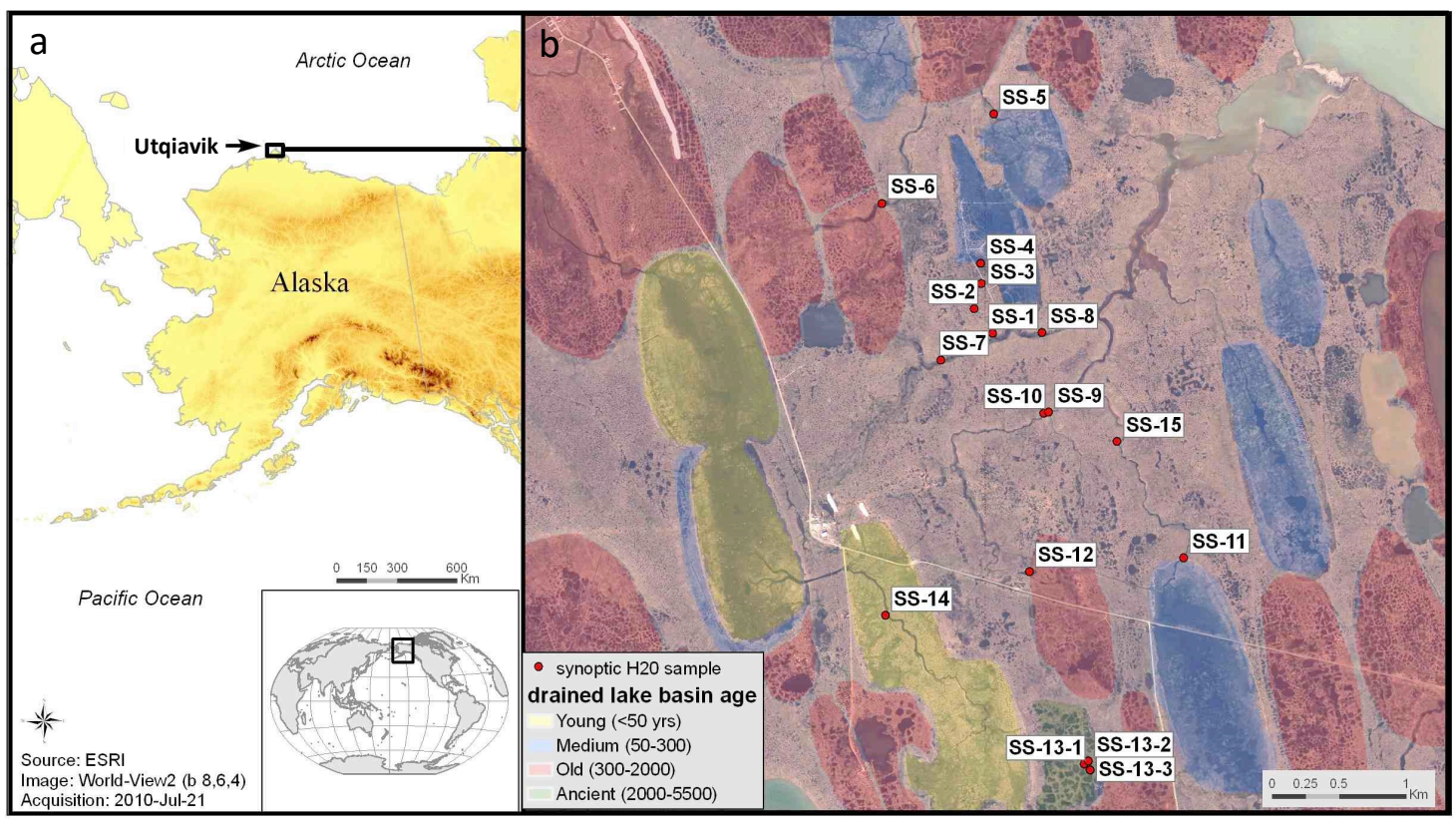

Figure 1: Location of Utquivik, Alaska, USA (a) and water sampling sites (b). Colours in (b) indicate different aged drained thaw lake basins (DTLB); see inset legend for ages (Hinkel et al., 2003). Reproduced from Throckmorton et al. (2015a).

\subsection{Surface and Soil Pore Water Measurements}

The chemistry of DOC was assessed based on spectral properties with UV-Vis absorbance (of samples filtered in the field through $0.45 \mu \mathrm{m}$ Fisher syringe filters) at room temperature (quartz tube; $1 \mathrm{~cm}$ path) at Los Alamos National Laboratory. Absorbance at 254, 350, and $440 \mathrm{~nm}$ were selected as spectral wavelengths of interest as they have been shown to correlate strongly with DOC concentration in rivers, particularly in those dominated by terrestrial organic matter inputs (Spencer et al.,

140 2012). Absorption coefficients were calculated following Eq. (1):

$\mathrm{a}_{\lambda}=\frac{2.303 * A_{\lambda}}{l}$,

where $A_{\lambda}$ is spectral absorbance at a specific wavelength $(\lambda)$ and $l$ is the cell path length in $\mathrm{m}$. We observed that absorption coefficients for all 3 wavelengths of interest positively correlated with DOC concentration $(p<0.01)$. Therefore, we weighted 
https://doi.org/10.5194/bg-2021-272

Preprint. Discussion started: 20 October 2021

(c) Author(s) 2021. CC BY 4.0 License.

(c) (i)

the absorbance coefficients by DOC concentration (in $\mathrm{m} \mathrm{L}^{-1}$ ) for further statistical analysis of carbon-specific ultraviolet

absorbance (SUVA) in $\mathrm{L} \mathrm{mgC}^{-1} \mathrm{~m}^{-1}$ for the targeted wavelengths as has been done by others previously (Weishaar et al., 2003). Some samples had absorbance less than the blank at 350 and $440 \mathrm{~nm}$ and were set to zero for further statistical analysis. SUVA values for 3 samples with DOC concentrations below $3 \mathrm{mg} \mathrm{L}^{-1}$ were removed as outliers because low DOC concentrations yielded very high SUVA values (1-2 orders of magnitude higher than the other samples).

Of the 102 total water samples collected, 80 had enough sample $(0.45 \mu \mathrm{m}$-filtered and stored in amber glass vials) after other analyses to send to Lawrence Livermore National Laboratory for radiocarbon analysis. Samples were freeze dried, treated with $1 \mathrm{~N} \mathrm{HCl}$ at $70^{\circ} \mathrm{C}$ to remove residual carbonate, and dried at $70^{\circ} \mathrm{C}$ to remove acid without rinsing. Samples were then combusted to $\mathrm{CO}_{2}$ and reduced to graphite onto $\mathrm{Fe}$ powder in the presence of $\mathrm{H}_{2}$ (Vogel et al., 1984). Measured $\delta^{13} \mathrm{C}$ values were used to correct for mass-dependent fractionation and ${ }^{14} \mathrm{C}$ values are reported as $\Delta{ }^{14} \mathrm{C}(\%)$ corrected to the year of measurement, either 2016 or 2017 (Stuiver and Polach, 1977).

A suite of biogeochemical indicators was analysed on these samples with results presented previously (Throckmorton et al., 2015b). These analytes add to the interpretation of the new data presented in this paper $\left({ }^{14} \mathrm{C}\right.$ of DOC and SUVA). Briefly, samples were analysed in the field for $\mathrm{Fe}^{2+}$, temperature, DO, and $\mathrm{pH}$. Samples were analysed at Los Alamos National Laboratory for concentrations and $\delta^{13} \mathrm{C}$ of dissolved $\mathrm{CH}_{4}$ and DIC (from samples filtered in the field through $0.2 \mu \mathrm{m}$ Fisher syringe filters), for concentrations and $\delta^{13} \mathrm{C}$ or $\delta^{15} \mathrm{~N}$ of DOC and DON (from samples filtered in the field through $0.45 \mu \mathrm{m}$

160 Fisher syringe filters); and major cations and trace metals (for more see Throckmorton et al., 2015b; Throckmorton et al., 2015a).

\subsection{Statistical Analysis}

Statistical analyses were performed in R v. 3.614 (R Core Team, 2019) at $\alpha=0.05$ for analyses of the entire dataset. Analyses for subsets that resulted in limited sample size (e.g., analysis of individual porewater depths or analysis of only the DTLB drainages) were performed at $\alpha=0.1$, as noted in the text. Pearson correlation analysis was used to assess dependence among DOC variables and other geochemical indicators using the Hmisc package (Harrell Jr, 2019). Depth and sampling month effects were tested using mixed effects models with repeated measures for depth and time using the nlme package 
https://doi.org/10.5194/bg-2021-272

Preprint. Discussion started: 20 October 2021

(c) Author(s) 2021. CC BY 4.0 License.

(c) (i)

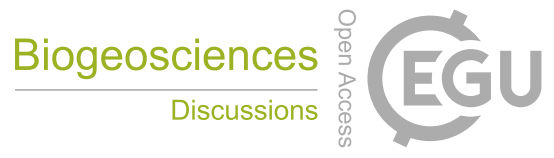

(Pinheiro et al., 2019). When present, interaction effects were investigated using the Phia package (De Rosario-Martinez, 2015). We evaluated the role of site characteristics in driving DOC characteristics using stepwise linear regression with the

MASS package (Venables and Ripley, 2002), which evaluates alternate regression models based on AIC criteria. Results are reported as means followed by standard deviations.

\section{Results and Discussion}

\subsection{Temporal and Depth Patterns of DOC Age and Chemistry}

DOC $\Delta{ }^{14} \mathrm{C}$ values ranged from $19 \%$ to $-583 \%$, or from an average conventional radiocarbon age of modern to 7000

175 y BP, and decreased from July to September $\left(\mathrm{p}<0.01\right.$, Fig. 2a), consistent with a decline in $\mathrm{DOC}{ }^{14} \mathrm{C}$ values from spring through late summer and fall reported for Arctic rivers and their tributaries (Neff et al., 2006; Wild et al., 2019). DOC $\Delta^{14} \mathrm{C}$
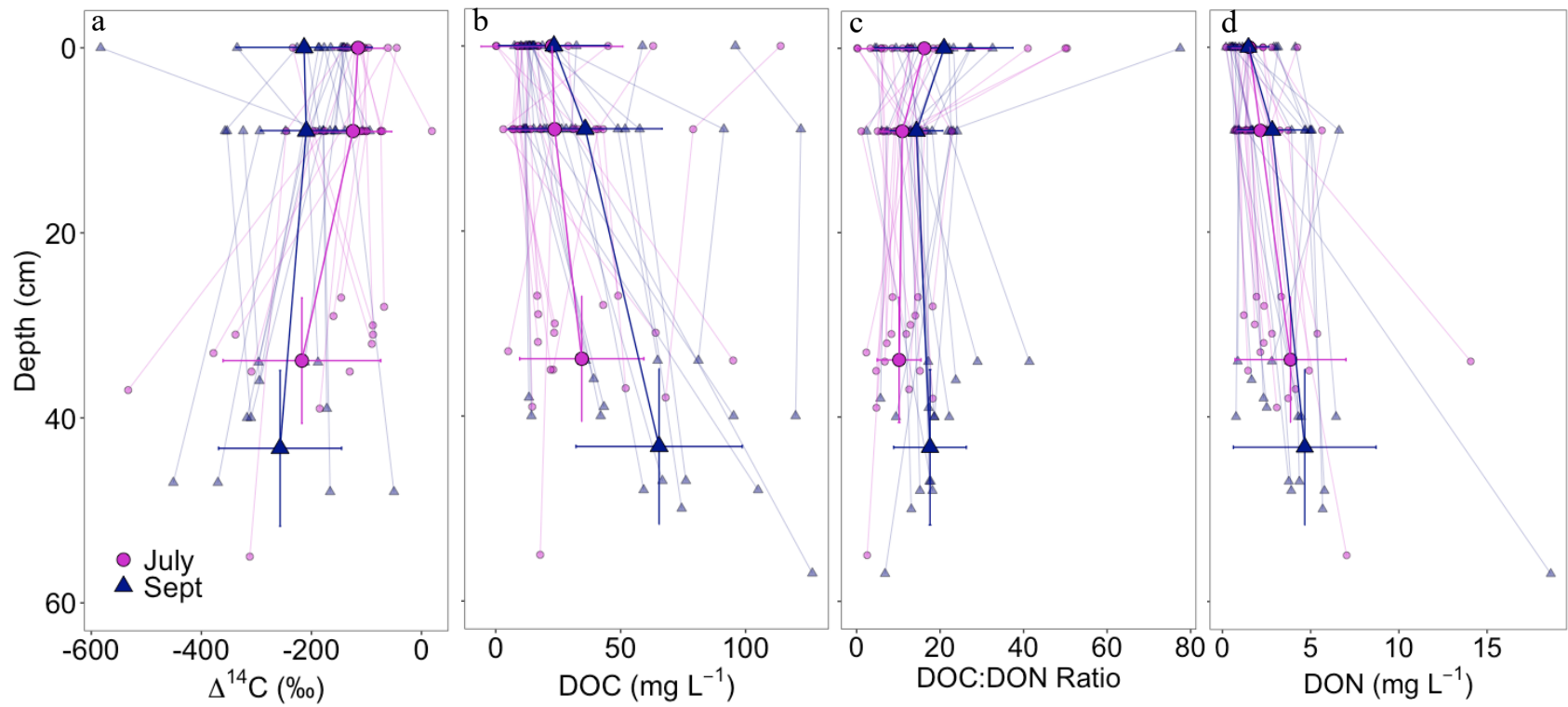

Figure 2. ${ }^{14} \mathrm{C}$ of DOC (a), DOC concentration (b), DOC:DON ratio (c), and DON concentration (d) by depth. Large symbols are means +/- SD. and DON concentration data were presented previously in Throckmorton et al., $2015 \mathrm{~b}$. 
https://doi.org/10.5194/bg-2021-272

Preprint. Discussion started: 20 October 2021

(c) Author(s) 2021. CC BY 4.0 License.

(c) (i)

185 also declined with depth, consistent with declines in ${ }^{14} \mathrm{C}$ values in soil pore-space $\mathrm{CO}_{2}$ with depth and from summer to fall in locations in our study area (Vaughn and Torn, 2018). DOC concentrations increased from July to September in samples from the thaw table depth $(\mathrm{p}<0.01)$ and increased with depth in September $(\mathrm{p}<0.01$, NS in July, Fig. $2 b)$. DOC concentration and ${ }^{14} \mathrm{C}$ values were not correlated to one another. Interestingly, DOC:DON ratio did not change with depth, but did increase from July to September $(p=0.01$, Fig. $2 c)$ - an indication that dissolved organic matter (DOM) quality or source may have shifted

190 over the summer. Dissolved organic nitrogen (DON) increased with depth $(\mathrm{p}<0.01)$ but did not change between July and September (Fig. 2d). These patterns are consistent with increased mobilization of undecomposed, vegetation-derived C from old permafrost as the thaw table deepened from an average of $34 \mathrm{~cm}$ in July to $43 \mathrm{~cm}$ in September.

We further assessed the chemistry of DOC with UV-vis absorbance at 254, 350, and $440 \mathrm{~nm}$ to identify trends in DOC chemical composition over the sampling period. We targeted these wavelengths because absorption increases with 195 increasing aromaticity at $254 \mathrm{~nm}$ (Weishaar et al., 2003), increasing lignin phenol content at $350 \mathrm{~nm}$ (Spencer et al., 2008; Mann et al., 2016), and increasing molecular size at $440 \mathrm{~nm}$ (Yacobi et al., 2003). We found that absorbances at all 3 wavelengths were positively correlated with DOC and DON concentrations (Figs. S1 and S2). Averaged across depths, the absorbance coefficient at $440 \mathrm{~nm}$ increased from $10 \mathrm{~m}^{-1}$ in July to $20 \mathrm{~m}^{-1}$ in September $(\mathrm{p}=0.03)$, consistent with a shift toward a more plant-derived source, but this difference was not significant when weighted by DOC concentration (SUVA440, $p=0.09$,

200 Fig. 3c). SUVA 350 increased with depth ( $p=0.03$, Fig. 3b), suggesting relatively higher lignin phenols at the thaw table where DOC was produced from actively thawing permafrost. Sampling month and depth effects on SUVA254 were not statistically significant. However, correlation analyses suggested SUVA 350 increased with increasing DON concentration $(\rho=0.26, p=$ $0.01)$ and $\mathrm{SUVA}_{254}$ increased with decreasing DOC:DON ratio $(\rho=-0.21, \mathrm{p}<0.01)$. Surprisingly, across the entire dataset, none of the SUVA indicators were correlated with DOC ${ }^{14} \mathrm{C}$ (Fig. S3). 
https://doi.org/10.5194/bg-2021-272

Preprint. Discussion started: 20 October 2021

(c) Author(s) 2021. CC BY 4.0 License.

(c) (i)

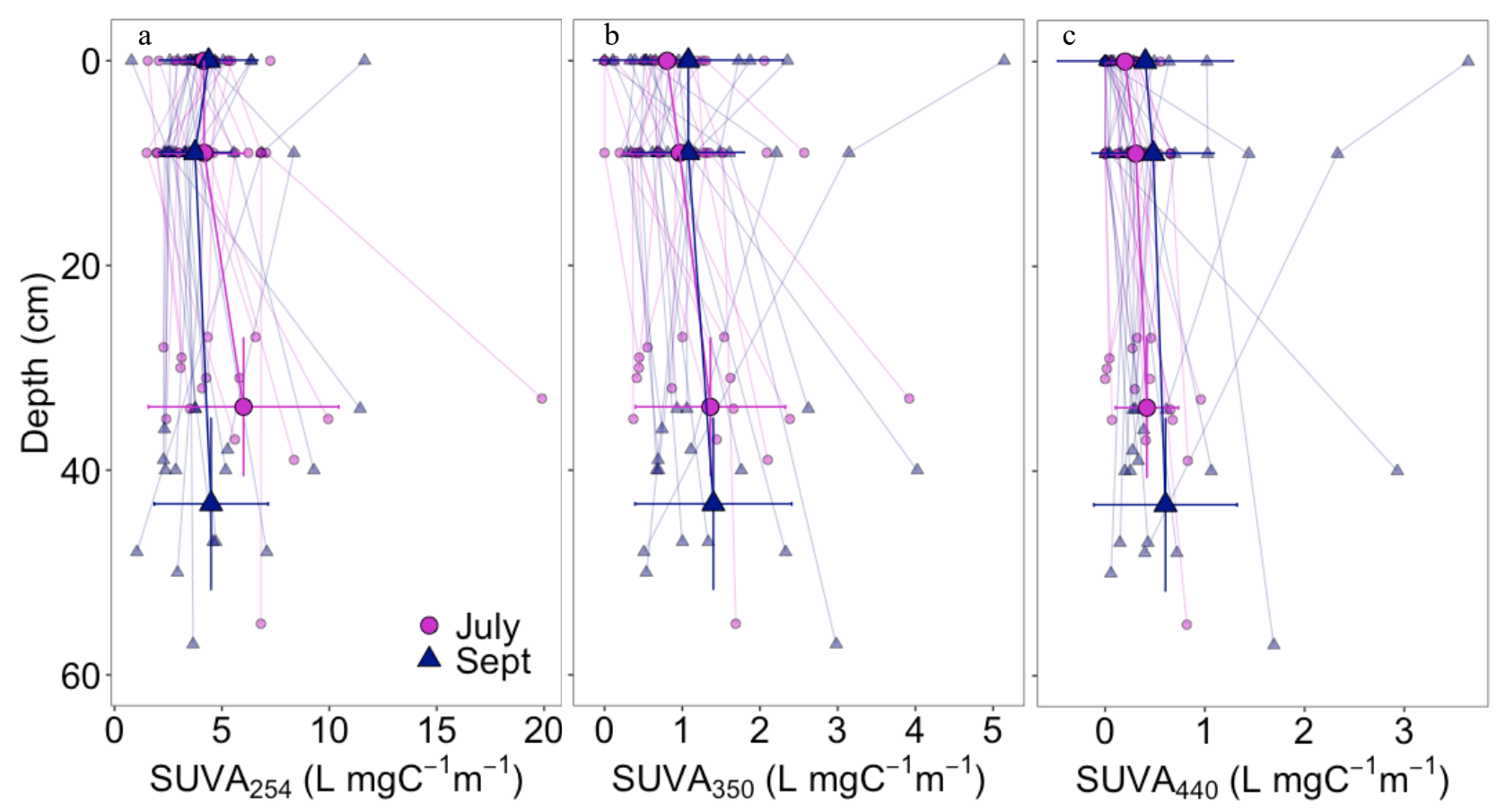

Figure 3. SUVA 254 (a), SUVA 350 (b), and SUVA 440 by depth. Large symbols are means +/- SD.

We observed SUVA254 values that are generally higher than those reported for Arctic rivers and streams, which tend to be less than $5 \mathrm{~L} \mathrm{mg} \mathrm{C}^{-1} \mathrm{~m}^{-1}$ (O'donnell et al., 2012; Spencer et al., 2008; Neff et al., 2006; Drake et al., 2018b), and within the range of those reported for soil leachates from elsewhere in northern Alaska (Gao et al., 2018; Whittinghill et al., 2014). Comparable SUVA 350 and SUVA440 for Arctic terrestrial or aquatic systems are not available in the literature, but in general, the absorption coefficients at these wavelengths observed in this study (Figures S1 and S2) are also higher than those reported for streams and rivers (Spencer et al., 2012; Mann et al., 2016; Spencer et al., 2008). Our observed patterns reflect a DOC 215 source that is high in plant-derived, aromatic, phenolic, and high molecular weight compounds throughout the summer. These trends likely reflect in situ production of DOC at depth from thawing permafrost that has not previously undergone microbial processing and may be biolabile. 
https://doi.org/10.5194/bg-2021-272

Preprint. Discussion started: 20 October 2021

(c) Author(s) 2021. CC BY 4.0 License.

(c) (i)

Other biogeochemical indicators (previously published by Throckmorton et al. (2015b)) also changed with sampling depth, consistent with other research on active layer hydrogeochemistry in the area (Newman et al., 2015). Specifically, concentrations of dissolved inorganic carbon (DIC), methane, $\mathrm{Fe}^{2+}$, and $\mathrm{Fe}^{3+}$ all increased with depth, while dissolved oxygen (DO) decreased with depth - trends that were attributed to increased availability and use of iron as a terminal electron acceptor in deeper mineral soils (Throckmorton et al., 2015b). Because many of the biogeochemical indicator species changed with depth, the relationship between these variables and DOC characteristics were further assessed separately by sampling depth (surface, shallow, or deep) with an alpha value of 0.1 to account for reduced sample size. In surface and shallow pore waters,

DOC $\Delta{ }^{14} \mathrm{C}$ values and $\mathrm{CH}_{4}$ concentrations were positively correlated (surface: $\rho=0.62, n=17, p<0.01$ and shallow: $\rho=0.53$, $\mathrm{n}=23, \mathrm{p}<0.01$, Fig. $4 \mathrm{a})$, reflecting decreases from July to September in both $\mathrm{DOC}{ }^{14} \mathrm{C}$ and $\mathrm{CH}_{4}$ concentrations $(\mathrm{p}=0.04)$.

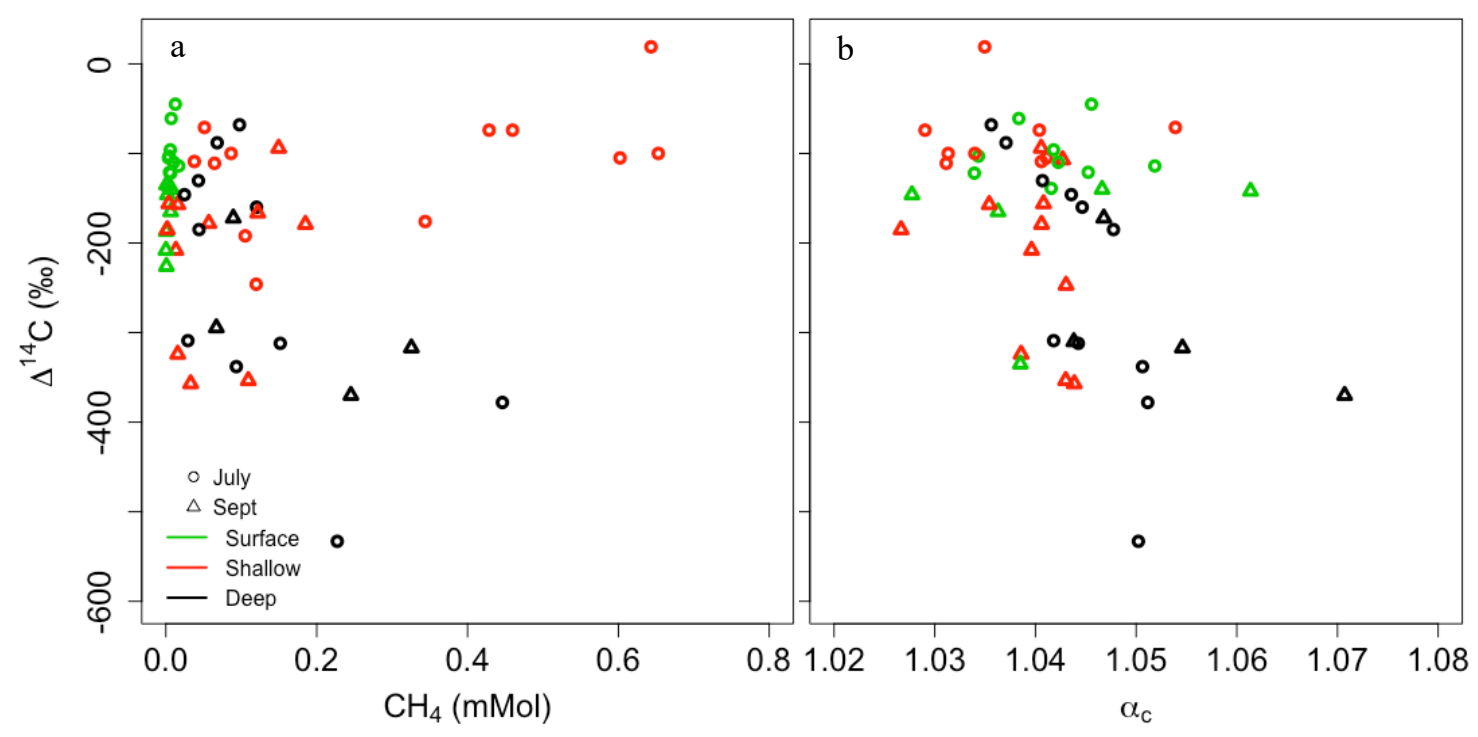

Figure 4. DOC ${ }^{14} \mathrm{C}$ (reported in this study) versus dissolved methane concentration (a) and the apparent fractionation factor for methanogenesis, $\alpha_{c}(b)$. Methane concentration, $\delta^{13} \mathrm{C}$, and $\alpha_{c}$ data were presented previously in Throckmorton et al., $2015 \mathrm{~b}$.

In contrast, deep pore water DOC $\Delta{ }^{14} \mathrm{C}$ was negatively correlated with DON $(\rho=-0.38, \mathrm{n}=24, \mathrm{p}=0.06), \mathrm{SUVA}_{350}$ $(\rho=-0.39, \mathrm{n}=24, \mathrm{p}=0.06), \operatorname{DIC}(\rho=-0.15, \mathrm{n}=21, \mathrm{p}=0.06), \mathrm{Fe}^{3+}(\rho=-0.65, \mathrm{n}=24, \mathrm{p}<0.01)$, and dissolved methane $(\rho=$ $-0.59, \mathrm{n}=15, \mathrm{p}=0.02$, Fig. 4a). None of these variables differed between sampling months, suggesting that these correlations 
https://doi.org/10.5194/bg-2021-272

Preprint. Discussion started: 20 October 2021

(c) Author(s) 2021. CC BY 4.0 License.

(c) (i)

reflect differences across sampling sites impacting carbon cycling and redox biogeochemistry. In addition to the trend of older

deep porewater DOC with increasing dissolved methane concentrations, deep porewater DOC ${ }^{14} \mathrm{C}$ values were positively correlated with $\delta^{13} \mathrm{C}_{\text {of }} \mathrm{CH}_{4}(\rho=0.45, \mathrm{n}=16, \mathrm{p}=0.08)$ and negatively correlated with the apparent fractionation factor $\left(\alpha_{\mathrm{c}}=\right.$ $\left.\left[\left(\delta^{13} \mathrm{CO}_{2}+1000\right) /\left(\delta^{13} \mathrm{CH}_{4}+1000\right)\right]\right)$ for methanogenesis $(\rho=-0.62, \mathrm{n}=15, \mathrm{p}=0.01$, Fig. $4 \mathrm{~b})$. Methane $\delta^{13} \mathrm{C}$ values can indicate the dominant pathway for methanogenesis (more depleted values associated with greater hydrogenotrophic methanogenesis and less depleted values associated with greater acetoclastic methanogenesis), but are also affected by other processes including diffusion and methanotrophy (Chanton, 2005). Thus, $\alpha_{c}$-values, which represent the difference in stable $C$ isotopic values of both DIC and $\mathrm{CH}_{4}$, are used to detect shifts in methanogenic pathways, with higher $\alpha_{\mathrm{c}}$-values indicative of hydrogenotrophic and lower $\alpha_{c}$-values typical of acetoclastic methanogenesis (Whiticar et al., 1986; Wilson et al., 2016; Hines et al., 2008). $\alpha_{c^{-}}$ values also increased with depth $(\mathrm{p}<0.01)$ and from July to September in deep porewaters only $(\mathrm{p}<0.01)$. The correlation between $\alpha_{\mathrm{c}}$-values and DOC ${ }^{14} \mathrm{C}$ values is likely not a causal relationship, but rather points to a tendency towards increased hydrogenotrophic relative to acetoclastic methanogenesis in deeper porewaters later in the summer when DOC:DON ratios were also higher.

Our study coincided with work by others on carbon cycling in our study area. Throckmorton et al., 2015 found that acetoclastic methanogensis was the dominant pathway for methane production at all 17 of our sampling locations in July, but that by September four drainages had become predominantly hydrogenotrophic (sites 3, 9, 10, and 15). Unfortunately, out of these 4 sites we only have $\mathrm{DOC}{ }^{14} \mathrm{C}$ for deep porewater in September for plot 10, but this sample has the oldest DOC age $\left({ }^{14} \mathrm{C}\right.$ $=-370 \%$ o) of the September samples with a measured $\delta^{13} \mathrm{C}_{\text {of }} \mathrm{CH}_{4}\left(-78.7 \%\right.$ ). Vaughn et al. (2016) measured $\mathrm{CO}_{2}$ and $\mathrm{CH}_{4}$ fluxes at sites across a permafrost degradation gradient within some of our study drainages. They found that more degraded sites had lower net $\mathrm{CH}_{4}$ emissions, higher $\mathrm{CH}_{4}$ oxidation, and methanogenesis dominated by the hydrogenotrophic pathway (Vaughn et al., 2016).

\subsection{Spatial Patterns of DOC Age and Chemistry}

Correlation analyses also suggested that DOC characteristics differed with sampling location features. DOC concentration decreased with increasing drainage size $(\rho=-0.22, p<0.01$, Fig. $5 a)$, which ranged from 0.8 to 171 ha. Stepwise 
https://doi.org/10.5194/bg-2021-272

Preprint. Discussion started: 20 October 2021

(c) Author(s) 2021. CC BY 4.0 License.

\section{(c) (i)}

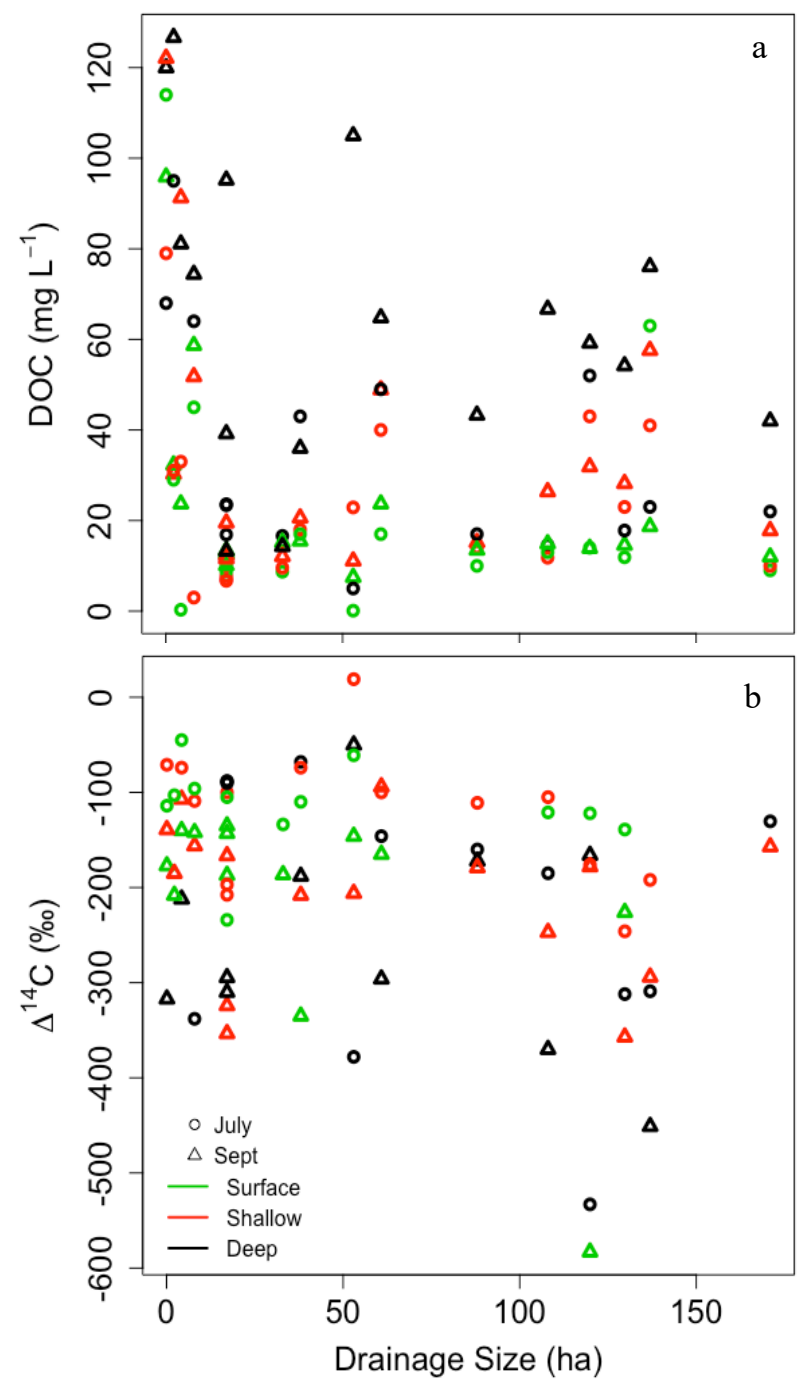

Figure 5. DOC concentration (a) and $\mathrm{DOC}{ }^{14} \mathrm{C}$ (b) versus drainage size.

linear regression indicated including drainage size improved model fit compared to depth and month alone. $\mathrm{DOC}{ }^{14} \mathrm{C}$ decreased with increasing drainage size $(\rho=-0.31, p<0.01)$. DOC ${ }^{14} \mathrm{C}$ was also correlated to water flow (stagnant or gentle flow observed upon sampling, $\rho=0.28, p=0.01$ ). Drainage size and water flow (stagnant or gentle flow) were correlated to one another ( $\rho$ $=-0.84, p<0.01$ ), such that wetland drainages with more stagnant waters tended to be smaller than channel drainages with 
https://doi.org/10.5194/bg-2021-272

Preprint. Discussion started: 20 October 2021

(c) Author(s) 2021. CC BY 4.0 License.

(c) (i)

265 gentle lateral flow, so stepwise linear regression was used to identify that the best model for predicting $\mathrm{DOC}{ }^{14} \mathrm{C}$ values included sampling month, depth, and drainage size. Controlling for month and depth, DOC ${ }^{14} \mathrm{C}$ values decreased with increasing drainage size $(p=0.01$, Fig. $5 b)$, likely reflecting greater production of relatively young DOC within the smaller drainages because these streams are not as deeply incised as the larger basins, and thus tap into a younger permafrost carbon reservoir. Others have reported that small headwater streams and catchments had higher DOC ${ }^{14} \mathrm{C}$ values (Neff et al., 2006), higher SUVA254 (Coch et al., 2019), and larger fractions of biodegradable DOC (Vonk et al., 2015a) than large rivers, while decreasing DOC with increasing size of thaw lakes has been observed in areas of Western Siberia undergoing permafrost thaw (Shirokova et al., 2013).

In the drained thaw lake basins (DTLBs), depth to the thaw table in young ( $<50$ years) and medium (50-300 years) aged DTLB's was shallower by $10 \mathrm{~cm}$ on average than in old (300-2000 years) and ancient (2000-5500 years) DTLBs (p < 275 0.01). In deep pore waters, DOC concentrations decreased with increasing basin age $(p=0.03$, Fig. 6a) controlling for depth and month. Also in deep pore waters, correlation analyses indicated that $\operatorname{SUVA}_{350}(\rho=-0.54, \mathrm{n}=16, \mathrm{p}=0.03$, Fig. $6 \mathrm{~b})$ and SUVA $_{440}(\rho=-0.66, n=16, p<0.01$, Fig. $6 c)$ decreased with increasing basin age, suggesting a decrease in lignin phenols and high molecular weight compounds associated with fresh vegetation-derived organic matter as DTLBs age. Our interpretation is limited, as we only sampled from 8 DTLBs, only one of which was younger than 50 years. However, these trends may reflect a decline in readily decomposable carbon and increase in the degree of organic matter decomposition as DTLB's age as reported across 77 basins on the Barrow Peninsula (Hinkel et al., 2003) and in Western Siberia thaw lakes, where DOC concentrations and high molecular weight compounds declined across a chronosequence of lake development (Pokrovsky et al., 2011). 
https://doi.org/10.5194/bg-2021-272

Preprint. Discussion started: 20 October 2021

(c) Author(s) 2021. CC BY 4.0 License.
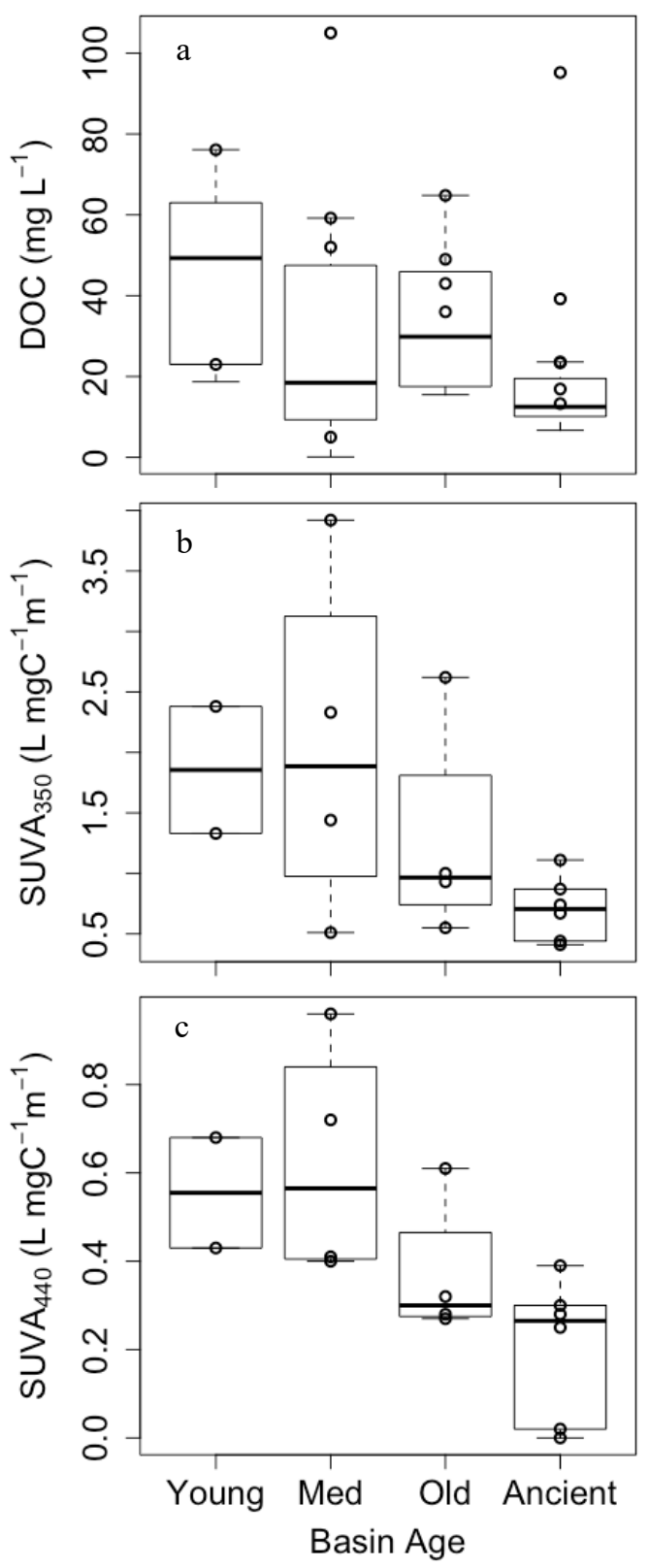

Figure 6. DOC concentration across depths (a), SUVA $A_{350}$ in deep pore waters $(b)$, and SUVA 440 in deep pore waters (c) versus DTLB age (young: < 50 years; medium: 50-300 years; old: 300-2000 years; and ancient 2000-5500 years). 
https://doi.org/10.5194/bg-2021-272

Preprint. Discussion started: 20 October 2021

(c) Author(s) 2021. CC BY 4.0 License.

(c) (i)

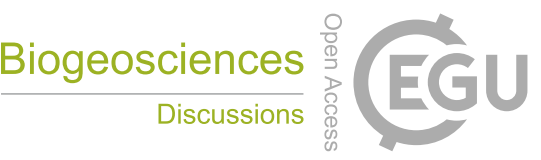

\section{Summary and Conclusions}

By studying 17 drainages in and around the Barrow Experimental Observatory, we found that DOC age and concentration in

290 surface, shallow pore, and deep pore waters increased with depth and as the thaw table deepened from July to September. We observed small shifts in DOC chemistry over the summer, including an increase in DOC:DON ratios and $\alpha_{440}$, the absorption coefficient that correlates with high molecular weight organic matter. Indicators of DOC chemistry reflected a DOC source consistent with unprocessed organic matter throughout the summer: high in aromaticity, lignin phenols, and high molecular weight compounds. Smaller wetland drainages released younger DOC that was higher in aromatics relative to larger drainage channels, while younger DTLBs released younger DOC that was higher in lignin phenols and high molecular weight compounds than older DTLBs. Across our study area, we found that older DOC and younger DOC have similar chemical indicators of lability, suggesting that the production of old and labile DOC may continue with increased permafrost thaw as the active layer deepens and thaw seasons lengthen in the northern Arctic.

\section{Data availability}

300 New data associated with this manuscript have been added to Throckmorton et al., 2015a. All data are available here: https://ngee-arctic.ornl.gov/data/pages/NGA027.html

\section{Supplement}

\section{Author Contribution}

KJM, HMT, JMH, BDN, and CJW designed the research. KJM, TPG, and CJW secured funding. HMT, JMH, BDN, and CJW

305 performed fieldwork. KJM, ALH, and HMT performed laboratory analyses. KJM performed data analysis. All authors contributed to interpretation. KJM wrote manuscript with input from all authors.

\section{Competing interests}

The authors declare that they have no conflict of interest. 
https://doi.org/10.5194/bg-2021-272

Preprint. Discussion started: 20 October 2021

(c) Author(s) 2021. CC BY 4.0 License.

(c) (i)

\section{Acknowledgements}

This work was funded by the Office of Biological and Environmental Research in the U.S. Department of Energy Office of Science through the Next-Generation Ecosystem Experiments (NGEE Arctic) project and Award SCW1447 to LLNL. This work was performed under the auspices of the U.S. Department of Energy by Lawrence Livermore National Laboratory under Contract DE-AC52-07NA27344 (LLNL-JRNL-808899) and by Los Alamos National Laboratory under contract DE-AC5206NA25396. The publisher, by accepting this work for publication, acknowledges that the United States Government retains a nonexclusive, paid-up, irrevocable, worldwide license to publish or reproduce this work or allow others to do so for the United States Government purposes.

\section{References}

Amon, R. M. W. and Meon, B.: The biogeochemistry of dissolved organic matter and nutrients in two large Arctic estuaries and potential implications for our understanding of the Arctic Ocean system, Marine Chemistry, 92, 311-330, 10.1016/j.marchem.2004.06.034, 2004.

Amon, R. M. W., Rinehart, A. J., Duan, S., Louchouarn, P., Prokushkin, A., Guggenberger, G., Bauch, D., Stedmon, C., Raymond, P. A., Holmes, R. M., McClelland, J. W., Peterson, B. J., Walker, S. A., and Zhulidov, A. V.: Dissolved organic matter sources in large Arctic rivers, Geochimica et Cosmochimica Acta, 94, 217-237, 10.1016/j.gca.2012.07.015, 2012.

Aurela, M., Laurila, T., and Tuovinen, J.-P.: Annual CO2 balance of a subarctic fen in northern Europe: Importance of the wintertime efflux, J. Geophys. Res., 107, 4607, 10.1029/2002jd002055, 2002.

Benner, R., Benitez-Nelson, B., Kaiser, K., and Amon, R. M. W.: Export of young terrigenous dissolved organic carbon from rivers to the Arctic Ocean, Geophysical Research Letters, 31, 10.1029/2003g1019251, 2004.

Billett, M. F., Palmer, S. M., Hope, D., Deacon, C., Storeton-West, R., Hargreaves, K. J., Flechard, C., and Fowler, D.: Linking landatmosphere-stream carbon fluxes in a lowland peatland system, Global Biogeochem. Cycles, 18, GB1024, 10.1029/2003gb002058, 2004.

Chanton, J. P.: The effect of gas transport on the isotope signature of methane in wetlands, Organic Geochemistry, 36, 753-768, 10.1016/j.orggeochem.2004.10.007, 2005.

Chanton, J. P., Glaser, P. H., Chasar, L. S., Burdige, D. J., Hines, M. E., Siegel, D. I., Tremblay, L. B., and Cooper, W. T.: Radiocarbon evidence for the importance of surface vegetation on fermentation and methanogenesis in contrasting types of boreal peatlands, Global Biogeochem. Cycles, 22, GB4022, 10.1029/2008gb003274, 2008.

Charman, D., Aravena, R., Bryant, C. L., and Harkness, D. D.: Carbon isotopes in peat, DOC, CO2, and CH4 in a Holocene peatland on Dartmoor, southwest England, Geology, 27, 539-542, 1999.

Christensen, T. R., Johansson, T., Olsrud, M., Ström, L., Lindroth, A., Mastepanov, M., Malmer, N., Friborg, T., Crill, P., and Callaghan, T. V.: A catchment-scale carbon and greenhouse gas budget of a subarctic landscape, Philosophical Transactions of the Royal Society A: Mathematical, Physical and Engineering Sciences, 365, 1643-1656, doi:10.1098/rsta.2007.2035, 2007.

Coch, C., Juhls, B., Lamoureux, S. F., Lafrenière, M. J., Fritz, M., Heim, B., and Lantuit, H.: Comparisons of dissolved organic matter and its optical characteristics in small low and high Arctic catchments, Biogeosciences, 16, 4535-4553, 10.5194/bg-16-4535-2019, 2019.

Cole, J. J., Prairie, Y. T., Caraco, N. F., McDowwell, W. H., Tranvik, L. J., Striegl, R. G., Duarte, C. M., Kortelainen, P., Downing, J. A., Middleburg, J. J., and Melack, J.: Plumbing the global carbon cycle: integrating inland waters into the terrestrial carbon budget, Ecosystems, 10, 171-184, DOI: 10.1007/s10021-006-9013-8, 2007.

Corbett, J. E., Tfaily, M., Burdige, D., Cooper, W., Glaser, P., and Chanton, J.: Partitioning pathways of CO2 production in peatlands with stable carbon isotopes, Biogeochemistry, 114, 327-340, 10.1007/s10533-012-9813-1, 2013.

De Rosario-Martinez, H.: phia: Post-Hoc Interaction Analysis [code], 2015. 
https://doi.org/10.5194/bg-2021-272

Preprint. Discussion started: 20 October 2021

(c) Author(s) 2021. CC BY 4.0 License.

Drake, T. W., Raymond, P. A., and Spencer, R. G. M.: Terrestrial carbon inputs to inland waters: A current synthesis of estimates and uncertainty, Limnology and Oceanography Letters, 3, 132-142, 10.1002/lol2.10055, 2018a.

Drake, T. W., Wickland, K. P., Spencer, R. G., McKnight, D. M., and Striegl, R. G.: Ancient low-molecular-weight organic acids in permafrost fuel rapid carbon dioxide production upon thaw, Proc Natl Acad Sci U S A, 112, 13946-13951, 10.1073/pnas.1511705112, 2015.

Drake, T. W., Guillemette, F., Hemingway, J. D., Chanton, J. P., Podgorski, D. C., Zimov, N. S., and Spencer, R. G. M.: The Ephemeral Signature of Permafrost Carbon in an Arctic Fluvial Network, Journal of Geophysical Research: Biogeosciences, 123, 1475-1485, 10.1029/2017jg004311, 2018b.

Fan, Z., Neff, J. C., and Wickland, K. P.: Modeling the production, decomposition, and tranport of dissolved organic carbon in boreal soils, Soil Science, 175, 223-232, 2010.

Finlay, J., Neff, J., Zimov, S., Davydova, A., and Davydov, S.: Snowmelt dominance of dissolved organic carbon in high-latitude watersheds: Implications for characterization and flux of river DOC, Geophysical Research Letters, 33, 10.1029/2006gl025754, 2006.

Freeman, C., Evans, C. D., Monteith, D. T., Reynolds, B., and Fenner, N.: Export of organic carbon from peat soils, Nature, 412, 785-785, 10.1038/35090628, 2001.

Frey, K. E.: Amplified carbon release from vast West Siberian peatlands by 2100, Geophysical Research Letters, 32, L09401, 10.1029/2004g1022025, 2005.

Frey, K. E. and McClelland, J. W.: Impacts of permafrost degradation on arctic river biogeochemistry, Hydrological Processes, 23, 169-182, 10.1002/hyp.7196, 2009.

Gao, L., Zhou, Z., Reyes, A. V., and Guo, L.: Yields and Characterization of Dissolved Organic Matter From Different Aged Soils in Northern Alaska, Journal of Geophysical Research: Biogeosciences, 123, 2035-2052, 10.1029/2018jg004408, 2018.

Guo, L. and Macdonald, R. W.: Source and transport of terrigenous organic matter in the upper Yukon River: Evidence from isotope ( $\delta 13 \mathrm{C}$, $\Delta 14 \mathrm{C}$, and $\delta 15 \mathrm{~N}$ ) composition of dissolved, colloidal, and particulate phases, Global Biogeochemical Cycles, 20, 10.1029/2005gb002593, 2006.

Guo, L., Ping, C.-L., and Macdonald, R. W.: Mobilization pathways of organic carbon from permafrost to arctic rivers in a changing climate, Geophysical Research Letters, 34, 10.1029/2007g1030689, 2007.

375 Harrell Jr, F. E.: Hmisc: Harrell Miscellaneous [code], 2019.

Hayes, D. J., Kicklighter, D. W., McGuire, A. D., Chen, M., Zhuang, Q., Yuan, F., Melillo, J. M., and Wullschleger, S. D.: The impacts of recent permafrost thaw on land-atmosphere greenhouse gas exchange, Environmental Research Letters, 9, 045005, 10.1088/17489326/9/4/045005, 2014.

Hicks Pries, C. E., Schuur, E. A. G., and Crummer, K. G.: Thawing permafrost increases old soil and autotrophic respiration in tundra: Partitioning ecosystem respiration using $\delta 13 \mathrm{C}$ and $\Delta 14 \mathrm{C}$, Global Change Biology, 19, 649-661, 10.1111/gcb.12058, 2013.

Hines, M. E., Duddleston, K. N., Rooney-Varga, J. N., Fields, D., and Chanton, J. P.: Uncoupling of acetate degradation from methane formation in Alaskan wetlands: Connections to vegetation distribution, Global Biogeochemical Cycles, 22, GB2017, 10.1029/2006gb002903, 2008.

Hinkel, K. M., Eisner, W. R., Bockheim, J. G., Nelson, F. E., Peterson, K. M., and Dai, X.: Spatial Extent, Age, and Carbon Stocks in Drained Thaw Lake Basins on the Barrow Peninsula, Alaska, Arctic, Antarctic, and Alpine Research, 35, 291-300, 10.1657/15230430(2003)035[0291:Seaacs]2.0.Co;2, 2003.

Holmes, R. M., McClelland, J. W., Raymond, P. A., Frazer, B. B., Peterson, B. J., and Stieglitz, M.: Lability of DOC transported by Alaskan rivers to the Arctic Ocean, Geophysical Research Letters, 35, L03402, 10.1029/2007g1032837, 2008.

Holmes, R. M., McClelland, J. W., Peterson, B. J., Tank, S. E., Bulygina, E., Eglinton, T. I., Gordeev, V. V., Gurtovaya, T. Y., Raymond, P. A., Repeta, D. J., Staples, R., Striegl, R. G., Zhulidov, A. V., and Zimov, S. A.: Seasonal and Annual Fluxes of Nutrients and Organic Matter from Large Rivers to the Arctic Ocean and Surrounding Seas, Estuaries and Coasts, 35, 369-382, 10.1007/s12237011-9386-6, 2011.

Johnston, S. E., Carey, J. C., Kellerman, A., Podgorski, D. C., Gewirtzman, J., and Spencer, R. G. M.: Controls on Riverine Dissolved Organic Matter Composition Across an Arctic-Boreal Latitudinal Gradient, J Geophys Res-Biogeo, 126, e2020JG005988, ARTN e2020JG005988 10.1029/2020JG005988, 2021.

Kawahigashi, M., Kaiser, K., Kalbitz, K., Rodionov, A., and Guggenberger, G.: Dissolved organic matter in small streams along a gradient from discontinuous to continuous permafrost, Global Change Biology, 10, 1576-1586, 10.1111/j.1365-2486.2004.00827.x, 2004.

Kellerman, A. M., Arellano, A., Podgorski, D. C., Martin, E. E., Martin, J. B., Deuerling, K. M., Bianchi, T. S., and Spencer, R. G. M.: Fundamental drivers of dissolved organic matter composition across an Arctic effective precipitation gradient, Limnology and Oceanography, 10.1002//no.11385, 2019.

Kling, G. W., Kipphut, G. W., and Miller., M. C.: Arctic Lakes and streams as gas conduits to the atmosphere: implications for tundra carbon budgets, Science, 251, 298-301, 1991. 
https://doi.org/10.5194/bg-2021-272

Preprint. Discussion started: 20 October 2021

(c) Author(s) 2021. CC BY 4.0 License.

Koven, C. D., Ringeval, B., Friedlingstein, P., Ciais, P., Cadule, P., Khvorostyanov, D., Krinner, G., and Tarnocai, C.: Permafrost carbonclimate feedbacks accelerate global warming, Proceedings of the National Academy of Sciences, 108, 14769-14774, 10.1073/pnas.1103910108, 2011.

Lapierre, J.-F., Guillemette, F., Berggren, M., and del Giorgio, P. A.: Increases in terrestrially derived carbon stimulate organic carbon processing and CO2 emissions in boreal aquatic ecosystems, Nature Communications, 4, 2972, 10.1038/ncomms3972, 2013.

Liu, F., Kou, D., Abbott, B. W., Mao, C., Chen, Y., Chen, L., and Yang, Y.: Disentangling the Effects of Climate, Vegetation, Soil and Related Substrate Properties on the Biodegradability of Permafrost-Derived Dissolved Organic Carbon, Journal of Geophysical Research: Biogeosciences, 124, 3377-3389, 10.1029/2018JG004944, 2019.

Mann, P. J., Davydova, A., Zimov, N., Spencer, R. G. M., Davydov, S., Bulygina, E., Zimov, S., and Holmes, R. M.: Controls on the composition and lability of dissolved organic matter in Siberia's Kolyma River basin, Journal of Geophysical Research: Biogeosciences, 117, G01028, 10.1029/2011jg001798, 2012.

Mann, P. J., Eglinton, T. I., McIntyre, C. P., Zimov, N., Davydova, A., Vonk, J. E., Holmes, R. M., and Spencer, R. G.: Utilization of ancient permafrost carbon in headwaters of Arctic fluvial networks, Nat Commun, 6, 7856, 10.1038/ncomms8856, 2015.

Mann, P. J., Spencer, R. G. M., Hernes, P. J., Six, J., Aiken, G. R., Tank, S. E., McClelland, J. W., Butler, K. D., Dyda, R. Y., and Holmes, R. M.: Pan-Arctic Trends in Terrestrial Dissolved Organic Matter from Optical Measurements, Frontiers in Earth Science, 4, 25, 2016.

McClelland, J. W., Holmes, R. M., Peterson, B. J., Raymond, P. A., Striegl, R. G., Zhulidov, A. V., Zimov, S. A., Zimov, N., Tank, S. E., Spencer, R. G. M., Staples, R., Gurtovaya, T. Y., and Griffin, C. G.: Particulate organic carbon and nitrogen export from major Arctic rivers, Global Biogeochemical Cycles, 30, 629-643, 10.1002/2015gb005351, 2016.

McGuire, A. D., Anderson, L. G., Christensen, T. R., Dallimore, S., Guo, L., Hayes, D. J., Heimann, M., Lorenson, T. D., Macdonald, R. W., and Roulet, N.: Sensitivity of the carbon cycle in the Arctic to climate change, Ecological Monographs, 79, 523-555, 10.1890/082025.1, 2009.

Molot, L. A. and Dillon, P. J.: Photolytic regulation of dissolved organic carbon in northern lakes, Global Biogeochemical Cycles, 11, 357$365,10.1029 / 97 \mathrm{gb01198,} 1997$.

Neff, J. C. and Hooper, D. U.: Vegetation and climate controls on potential $\mathrm{CO}_{2}$, DOC and DON production in northern latitude soils, Global Change Biology, 8, 872-884, 2002.

Neff, J. C., Finlay, J. C., Zimov, S. A., Davydov, S. P., Carrasco, J. J., Schuur, E. A. G., and Davydova, A. I.: Seasonal changes in the age and structure of dissolved organic carbon in Siberian rivers and streams, Geophys. Res. Lett., 33, L23401, 10.1029/2006gl028222, 2006.

Newman, B. D., Throckmorton, H. M., Graham, D. E., Gu, B., Hubbard, S. S., Liang, L., Wu, Y., Heikoop, J. M., Herndon, E. M., Phelps, T. J., Wilson, C. J., and Wullschleger, S. D.: Microtopographic and depth controls on active layer chemistry in Arctic polygonal ground, Geophysical Research Letters, 42, 1808-1817, 10.1002/2014g1062804, 2015.

O'Donnell, J. A., Aiken, G. R., Walvoord, M. A., and Butler, K. D.: Dissolved organic matter composition of winter flow in the Yukon River basin: Implications of permafrost thaw and increased groundwater discharge, Global Biogeochemical Cycles, 26, GB0E06, 10.1029/2012gb004341, 2012.

Olefeldt, D. and Roulet, N. T.: Effects of permafrost and hydrology on the composition and transport of dissolved organic carbon in a subarctic peatland complex, Journal of Geophysical Research: Biogeosciences, 117, G01005, 10.1029/2011jg001819, 2012.

Pastor, J., Solin, J., Bridgham, S. D., Updegraff, K., Harth, C., Weishampel, P., and Dewey, B.: Global warming and the export of dissolved organic carbon from boreal peatlands, Oikos, 100, 380-386, 10.1034/j.1600-0706.2003.11774.x, 2003.

Pinheiro, J., Bates, D., DebRoy, S., Sarkar, D., and R Core Team: nlme: Linear and Nonlinear Mixed Effects Models [code], 2019.

Pokrovsky, O. S., Shirokova, L. S., Kirpotin, S. N., Audry, S., Viers, J., and Dupré, B.: Effect of permafrost thawing on organic carbon and trace element colloidal speciation in the thermokarst lakes of western Siberia, Biogeosciences, 8, 565-583, 10.5194/bg-8-565-2011, 2011.

Prokushkin, A. S., Pokrovsky, O. S., Shirokova, L. S., Korets, M. A., Viers, J., Prokushkin, S. G., Amon, R. M. W., Guggenberger, G., and McDowell, W. H.: Sources and the flux pattern of dissolved carbon in rivers of the Yenisey basin draining the Central Siberian Plateau, Environmental Research Letters, 6, 045212, 10.1088/1748-9326/6/4/045212, 2011.

450 R Core Team: R: A language and environment for statistical computing., R Foundation for Statistical Computing [code], 2019.

Raymond, P. A., Saiers, J. E., and Sobczak, W. V.: Hydrological and biogeochemical controls on watershed dissolved organic matter transport: pulse-shunt concept, Ecology, 97, 5-16, 10.1890/14-1684.1, 2016.

Raymond, P. A., McClelland, J. W., Holmes, R. M., Zhulidov, A. V., Mull, K., Peterson, B. J., Striegl, R. G., Aiken, G. R., and Gurtovaya, T. Y.: Flux and age of dissolved organic carbon exported to the Arctic Ocean: A carbon isotopic study of the five largest arctic rivers, Global Biogeochemical Cycles, 21, GB4011, 10.1029/2007gb002934, 2007.

Roulet, N. T., Lafleur, P. M., Richard, P. J. H., Moore, T. R., Humphreys, E. R., and Bubier, J.: Contemporary carbon balance and late Holocene carbon accumulation in a northern peatland, Global Change Biology, 13, 397-411, 10.1111/j.1365-2486.2006.01292.x, 2007. 
https://doi.org/10.5194/bg-2021-272

Preprint. Discussion started: 20 October 2021

(c) Author(s) 2021. CC BY 4.0 License.

Schadel, C., Bader, M. K. F., Schuur, E. A. G., Biasi, C., Bracho, R., Capek, P., De Baets, S., Diakova, K., Ernakovich, J., Estop-Aragones, C., Graham, D. E., Hartley, I. P., Iversen, C. M., Kane, E. S., Knoblauch, C., Lupascu, M., Martikainen, P. J., Natali, S. M., Norby, R. J., O'Donnell, J. A., Chowdhury, T. R., Santruckova, H., Shaver, G., Sloan, V. L., Treat, C. C., Turetsky, M. R., Waldrop, M. P., and Wickland, K. P.: Potential carbon emissions dominated by carbon dioxide from thawed permafrost soils, Nature Climate Change, 6, 950-953, 10.1038/Nclimate3054, 2016.

Schaefer, K., Lantuit, H., Romanovsky, V. E., Schuur, E. A. G., and Witt, R.: The impact of the permafrost carbon feedback on global climate, Environmental Research Letters, 9, 085003, 10.1088/1748-9326/9/8/085003, 2014.

Schuur, E. A., McGuire, A. D., Schadel, C., Grosse, G., Harden, J. W., Hayes, D. J., Hugelius, G., Koven, C. D., Kuhry, P., Lawrence, D. M., Natali, S. M., Olefeldt, D., Romanovsky, V. E., Schaefer, K., Turetsky, M. R., Treat, C. C., and Vonk, J. E.: Climate change and the permafrost carbon feedback, Nature, 520, 171-179, 10.1038/nature14338, 2015.

Schuur, E. A. G., Bockheim, J., Canadell, J. G., Euskirchen, E., Field, C. B., Goryachkin, S. V., Hagemann, S., Kuhry, P., Lafleur, P. M., Lee, H., Mazhitova, G., Nelson, F. E., Rinke, A., Romanovsky, V. E., Shiklomanov, N., Tarnocai, C., Venevsky, S., Vogel, J. G., and Zimov, S. A.: Vulnerability of permafrost carbon to climate change: Implications for the global carbon cycle, Bioscience, 58 , 701-714, 10.1641/B580807, 2008.

Schuur, E. A. G., Abbott, B. W., Bowden, W. B., Brovkin, V., Camill, P., Canadell, J. G., Chanton, J. P., Chapin, F. S., III, Christensen, T. R., Ciais, P., Crosby, B. T., Czimczik, C. I., Grosse, G., Harden, J., Hayes, D. J., Hugelius, G., Jastrow, J. D., Jones, J. B., Kleinen, T., Koven, C. D., Krinner, G., Kuhry, P., Lawrence, D. M., McGuire, A. D., Natali, S. M., O’Donnell, J. A., Ping, C. L., Riley, W. J., Rinke, A., Romanovsky, V. E., Sannel, A. B. K., Schädel, C., Schaefer, K., Sky, J., Subin, Z. M., Tarnocai, C., Turetsky, M. R., Waldrop, M. P., Walter Anthony, K. M., Wickland, K. P., Wilson, C. J., and Zimov, S. A.: Expert assessment of vulnerability of permafrost carbon to climate change, Climatic Change, 119, 359-374, 10.1007/s10584-013-0730-7, 2013.

Shirokova, L. S., Pokrovsky, O. S., Kirpotin, S. N., Desmukh, C., Pokrovsky, B. G., Audry, S., and Viers, J.: Biogeochemistry of organic carbon, $\mathrm{CO} 2, \mathrm{CH} 4$, and trace elements in thermokarst water bodies in discontinuous permafrost zones of Western Siberia, Biogeochemistry, 113, 573-593, 10.1007/s10533-012-9790-4, 2013.

Shogren, A. J., Zarnetske, J. P., Abbott, B. W., Iannucci, F., Frei, R. J., Griffin, N. A., and Bowden, W. B.: Revealing biogeochemical signatures of Arctic landscapes with river chemistry, Scientific Reports, 9, 12894, 10.1038/s41598-019-49296-6, 2019.

Spencer, R. G. M., Butler, K. D., and Aiken, G. R.: Dissolved organic carbon and chromophoric dissolved organic matter properties of rivers in the USA, Journal of Geophysical Research: Biogeosciences, 117, doi:10.1029/2011JG001928, 2012.

Spencer, R. G. M., Aiken, G. R., Wickland, K. P., Striegl, R. G., and Hernes, P. J.: Seasonal and spatial variability in dissolved organic matter quantity and composition from the Yukon River basin, Alaska, Global Biogeochemical Cycles, 22, 10.1029/2008gb003231, 2008.

Striegl, R. G., Dornblaser, M. M., Aiken, G. R., Wickland, K. P., and Raymond, P. A.: Carbon export and cycling by the Yukon, Tanana, and Porcupine rivers, Alaska, 2001-2005, Water Resources Research, 43, 10.1029/2006wr005201, 2007.

Stuiver, M. and Polach, H. A.: Reporting of C-14 data, Radiocarbon, 19, 355-363, 1977.

Tank, S. E., Fellman, J. B., Hood, E., and Kritzberg, E. S.: Beyond respiration: Controls on lateral carbon fluxes across the terrestrial-aquatic interface, Limnology and Oceanography Letters, 3, 76-88, 10.1002/lol2.10065, 2018.

Tarnocai, C., Canadell, J. G., Schuur, E. A. G., Kuhry, P., Mazhitova, G., and Zimov, S.: Soil organic carbon pools in the northern circumpolar permafrost region, Global Biogeochemical Cycles, 23, GB2023, 10.1029/2008gb003327, 2009.

Textor, S. R., Wickland, K. P., Podgorski, D. C., Johnston, S. E., and Spencer, R. G. M.: Dissolved Organic Carbon Turnover in PermafrostInfluenced Watersheds of Interior Alaska: Molecular Insights and the Priming Effect, Frontiers in Earth Science, 7, 10.3389/feart.2019.00275, 2019.

Throckmorton, H. M., Heikoop, J. M., McFarlane, K., Newman, B. D., and Wilson, C. J.: Inorganic Carbon Isotopes and Chemical Characterization of Watershed Drainages, Barrow, Alaska, 2013, U.S. Department of Energy, Oak Ridge national Laboratory [dataset], 10.5440/1221564, 2015a.

Throckmorton, H. M., Heikoop, J. M., Newman, B. D., Altmann, G. L., Conrad, M. S., Muss, J. D., Perkins, G. B., Smith, L. J., Torn, M. S., Wullschleger, S. D., and Wilson, C. J.: Pathways and transformations of dissolved methane and dissolved inorganic carbon in Arctic tundra watersheds: Evidence from analysis of stable isotopes, Global Biogeochemical Cycles, 29, 1893-1910, $10.1002 / 2014 \mathrm{gb} 005044,2015 \mathrm{~b}$.

Townsend-Small, A., McClelland, J. W., Max Holmes, R., and Peterson, B. J.: Seasonal and hydrologic drivers of dissolved organic matter and nutrients in the upper Kuparuk River, Alaskan Arctic, Biogeochemistry, 103, 109-124, 10.1007/s10533-010-9451-4, 2011.

Vaughn, L. J., Conrad, M. E., Bill, M., and Torn, M. S.: Isotopic insights into methane production, oxidation, and emissions in Arctic polygon tundra, Glob Chang Biol, 22, 3487-3502, 10.1111/gcb.13281, 2016.

510 Vaughn, L. J. S. and Torn, M. S.: Radiocarbon measurements of ecosystem respiration and soil pore-space CO2 in Utqiagivik (Barrow), Alaska, Earth Syst. Sci. Data, 10, 1943-1957, 10.5194/essd-10-1943-2018, 2018.

Venables, W. N. and Ripley, B. D.: Modern Applied Statistics with S, Fourth, Springer, New York2002. 
https://doi.org/10.5194/bg-2021-272

Preprint. Discussion started: 20 October 2021

(c) Author(s) 2021. CC BY 4.0 License.

(c) (i)

Vogel, J. S., Southon, J. R., Nelson, D. E., and Brown, T. A.: Performance of catalytically condensed carbon for use in accelerator massspectrometry, Nuclear Instruments and Methods in Physics Research Section B: Beam Interactions with Materials and Atoms, 5, 289-293, 10.1016/0168-583X(84)90529-9, 1984.

Vonk, J. E., Tank, S. E., and Walvoord, M. A.: Integrating hydrology and biogeochemistry across frozen landscapes, Nature Communications, 10, 5377, 10.1038/s41467-019-13361-5, 2019.

Vonk, J. E., Tank, S. E., Mann, P. J., Spencer, R. G. M., Treat, C. C., Striegl, R. G., Abbott, B. W., and Wickland, K. P.: Biodegradability of dissolved organic carbon in permafrost soils and aquatic systems: a meta-analysis, Biogeosciences, 12, 6915-6930, 10.5194/bg12-6915-2015, 2015a.

Vonk, J. E., Mann, P. J., Davydov, S., Davydova, A., Spencer, R. G. M., Schade, J., Sobczak, W. V., Zimov, N., Zimov, S., Bulygina, E., Eglinton, T. I., and Holmes, R. M.: High biolability of ancient permafrost carbon upon thaw, Geophysical Research Letters, 40, 26892693, 10.1002/grl.50348, 2013.

Vonk, J. E., Tank, S. E., Bowden, W. B., Laurion, I., Vincent, W. F., Alekseychik, P., Amyot, M., Billet, M. F., Canário, J., Cory, R. M., Deshpande, B. N., Helbig, M., Jammet, M., Karlsson, J., Larouche, J., MacMillan, G., Rautio, M., Walter Anthony, K. M., and Wickland, K. P.: Reviews and syntheses: Effects of permafrost thaw on Arctic aquatic ecosystems, Biogeosciences, 12, 7129-7167, 10.5194/bg-12-7129-2015, 2015b.

Weishaar, J. L., Aiken, G. R., Bergamaschi, B. A., Fram, M. S., Fujii, R., and Mopper, K.: Evaluation of Specific Ultraviolet Absorbance as an Indicator of the Chemical Composition and Reactivity of Dissolved Organic Carbon, Environmental Science \& Technology, 37, 4702-4708, 10.1021/es030360x, 2003.

Whiticar, M. J., Faber, E., and Schoell, M.: Biogenic methane formation in marine and freshwater environments: CO2 reduction vs. acetate fermentation-Isotope evidence, Geochimica et Cosmochimica Acta, 50, 693-709, https://doi.org/10.1016/0016-7037(86)90346-7, 1986.

Whittinghill, K. A., Finlay, J. C., and Hobbie, S. E.: Bioavailability of dissolved organic carbon across a hillslope chronosequence in the Kuparuk River region, Alaska, Soil Biology and Biochemistry, 79, 25-33, https://doi.org/10.1016/j.soilbio.2014.08.020, 2014.

Wild, B., Andersson, A., Bröder, L., Vonk, J., Hugelius, G., McClelland, J. W., Song, W., Raymond, P. A., and Gustafsson, Ö.: Rivers across the Siberian Arctic unearth the patterns of carbon release from thawing permafrost, Proceedings of the National Academy of Sciences, 116, 10280, 10.1073/pnas.1811797116, 2019.

Wild, B., Schnecker, J., Alves, R. J. E., Barsukov, P., Bárta, J., Čapek, P., Gentsch, N., Gittel, A., Guggenberger, G., Lashchinskiy, N., Mikutta, R., Rusalimova, O., Šantrůčková, H., Shibistova, O., Urich, T., Watzka, M., Zrazhevskaya, G., and Richter, A.: Input of easily available organic $\mathrm{C}$ and $\mathrm{N}$ stimulates microbial decomposition of soil organic matter in arctic permafrost soil, Soil Biology and Biochemistry, 75, 143-151, https://doi.org/10.1016/j.soilbio.2014.04.014, 2014.

Wilson, R. M., Hopple, A. M., Tfaily, M. M., Sebestyen, S. D., Schadt, C. W., Pfeifer-Meister, L., Medvedeff, C., McFarlane, K. J., Kostka, J. E., Kolton, M., Kolka, R. K., Kluber, L. A., Keller, J. K., Guilderson, T. P., Griffiths, N. A., Chanton, J. P., Bridgham, S. D., and Hanson, P. J.: Stability of peatland carbon to rising temperatures, Nature Communications, 7, 13723, 10.1038/ncomms13723, 2016.

Yacobi, Y., Alberts, J., Takacs, M., and McElvaine, M.: Absorption spectroscopy of colored dissolved organic carbon in Georgia (USA) rivers: the impact of molecular size distribution, Journal of Limnology, 62, 41-46, 10.4081/jlimnol.2003.41, 2003. 